\title{
のこぎり歯形形状を有する表面によるマイクロパーツの輸送*
}

\author{
三谷篤 史 ${ }^{* 1}$, 菅野直 ${ }^{* 1}$, 平井慎 一*2
}

\section{Micro-Parts Feeding by a Saw-tooth Surface}

\author{
Atsushi MITANI, Naoto SUGANO and Shin-ichi HIRAI*3 \\ ${ }^{* 3}$ Faculty of Science and Engineering, Ritsumeikan University \\ 1.1 1 Noji Higashi, Kusatsu shi, Shiga, 525-8577 Japan
}

\begin{abstract}
This paper describes micro-parts feeding using a saw-tooth surface. In parts feeding, a driving force applied to each part must vary according to the moving direction of the part so that the part moves in one dirction. Traditional feeders employ oblique vibration or asymmetric vibration of a feeder surface, which aften causes unstable motion of micro-parts. In this paper, we propose microparts feeding using a saw-tooth surface with simple planar and symmetric vibration. First, we describe the principle of the proposed parts feeding. Contact model between a micro-part and a saw ${ }^{-}$ tooth is then analyzed to formulate the condition for the feeding. Next, we show experimental results to examine whether the proposed method performs micro-parts feeding. Finally, we discuss how the feeding model explains experimental results.
\end{abstract}

Key Words: Saw tooth Surface, Micro-Parts, Feeding, Directionality

\section{1.はじめに}

近年, 電子機器の小型化に対する要求や, 携帯電話 などモバイル機器の普及とともに，基板実装用小型抵 抗・コンデンサなどのマイクロパーツが大量に生産・ 消費されている. マイクロパーツは出荷前の検査とし て, 欠けやクラック, 素体不良などによる不良品を選 別するため, 全 6 面の外観検査を行う. 現在これらの プロセスは自動化されており，複数台のカメラによる 外観検查を行う装直と，マイクロパーツフィーダと呼 ばれる振動式パーツ輸送装置を用いて行われている。

マイクロパーツのように微小かつ軽量な輸送対象物 (ワーク)の接触運動においては, 重力など体積に比例 する力に比して, 接触面積に比例する凝着力の効果が 支配的である ${ }^{(1)}$. したがって，マイクロパーツフィー ダには，凝着力に打ち克つための慣性力をパーツに伝 えることが必要である．また，パーツをある一方向へ 輸送するために，輸送方向に対する正方向と逆方向で 異なった駆動力を与える必要がある.

本研究では, フィーダの表面にのこぎり歯形状の䓓 加工を施し, 正負方向の接触条件を変えることによっ て，対称な平面振動を用いて一方向輸送を実現する方 法を提案する. 微小かつ軽量なワークの運動において

* 原稿受付 2004 年 6 月 18 H.

*1 主命館大学理:学研究科( 525-8577 草津市野路東 1111 ).

*2 䜣員, 立命館大学理工学部.

E mail : amv23017 (a se.ritsumei.ac.jp
は，フィーダ表面から受ける力の影響が慣性力の影響 よりも大きくなる.これらの点に着目寸れば, 振動式 フィーダの入力信号波形や駆動周波数を変更するより むしろ, ワークとフィーダ表面の接触条件を変更する 方が，ワークの運動により大きな影響を与えられる. フィーダ表面に加工を施すことにより，フィーダとワー クの接触面積が減少し, 凝着力による影響の低减が期 待できる. 対称な駆動信号による振動を利用する場合, 鋸波状波などの非対称駆動信号に比して高効率な駆動 が期待できる．また，フィーダ表面形状によってパー ツの運動を変えられれば, パーツフィーダの駆動周波 数や振動振幅，機械的な傾きを変えることなくパーツ の分離や整列が可能となる.

従来のパーツフィーダは, 水平方向への振動だけで なく垂直方向への振動を利用しており，斜め振動や機 械的な傾きを利用する方法 ${ }^{(2)}(3)$ や, 水平方向と垂直方 向それぞれに振動を与える方法 ${ }^{(4)}$ が提案されている. これらの方式では, 垂直方向の振動によるワークの跳 躍の問題がつきまとうため, 安定な輸送を実現するた めには，傾き角や駆動周波数の微調整が必要となる. また, 正・逆方向の加速度を変化させることにより一 方向の慣性力を得る方法が提案されている(5) (8).こ れらは，鋸波状波や非正弦波など非対称な駆動信号や パルス信号を用いるため, 駆動周波数を上げることが 困難であり，対称波駆動に比してエネルギ効率が低く 
なる．表面に微小な加工を施すことにより，凝着力を 低減する方法についての研究は行われている ${ }^{(9)}$. しか し, 表面形状により輸送の方向性を得る方法について は言及されていない.

本論文では，フィーダ表面としてのこぎり歯形状を 適用し，方形波信号による水平振動を与えた場合のマ イクロパーツの挙動を, 実験的に明らかにする.

\section{2. 輸送原理}

パーツフィーダにおいて, ワークがある一方向へ運 動するためには，フィーダ表面からワークに伝わる駆 動力が正負方向で異なる必要がある。本章では，ワー クであるマイクロパーツについて述べ，ワークとのこ ぎり菌形状表面との接触状態を仮定することにより一 方向輸送の理論的検討を行う。

本研究で対象とするワークは, 積層セラミックコン デンサである. 図 1 にセラミックコンデンサの外観を, 表 1 に TDK 製 C シリーズコンデンサの仕様を示す. これらのセラミックコンデンサは, セラミック誘導体 部とその両端に取付けられた外部電極により構成され る. 図 2 は，2012 型の表面を接触式あらさ測定器で 計測した結果である. 外部電極がセラミック誘導体部 より約 $40 \mu \mathrm{m}$ 突出していることがわかる. したがって, パーツフィーダ表面との接触は外部電極において発生 する，また，外部電極の表面は平らでなく，多くの凹 凸が存在することがわかる.

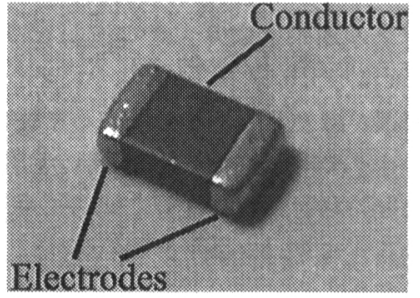

Fig. 1 Overview of ceramic condenser 2012

Table 1 TDK C series specification

\begin{tabular}{|c|c|r|}
\hline Type & Size $\left(\mathrm{t} \times \mathrm{w} \times \mathrm{h}\left[\mathrm{mm}^{3}\right]\right)$ & Weight $[\mathrm{mg}]$ \\
\hline 0603 & $0.6 \times 0.3 \times 0.3$ & 0.3 \\
\hline 1005 & $1.0 \times 0.5 \times 0.5$ & 1.2 \\
\hline 2012 & $2.0 \times 1.2 \times 0.6$ & 7.5 \\
\hline 3216 & $3.2 \times 1.6 \times 0.85$ & 23.0 \\
\hline
\end{tabular}

ワークの外部電極表面に存在する凸部や凹部が，図 3 に示すように半径 $r$ の円弧であると仮定し, パーツ フィーダの表面が図 4 で示すのこぎり歯形状であると 仮定する。のこぎり歯の仰角を，図 4 に示すように $\theta$

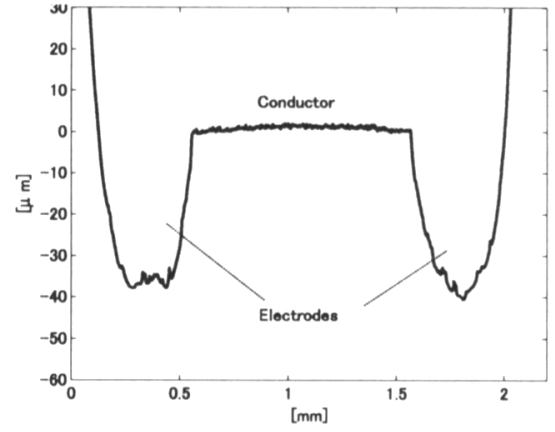

Fig. 2 Surface shape of ceramic condensor 2012

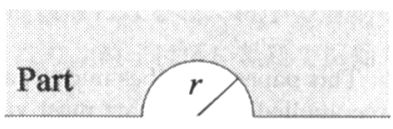

(a) concavity

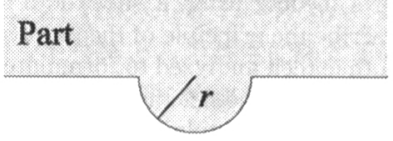

(b) convexity

Fig. 3 Surface profile model

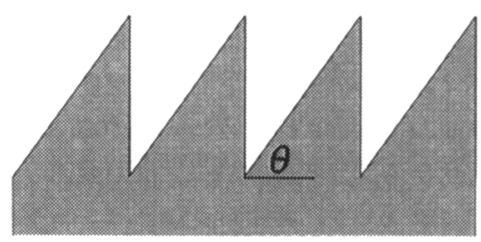

Fig. 4 Saw-tooth surface model

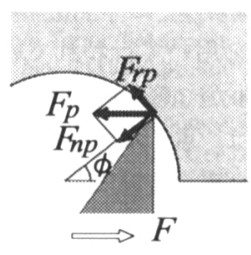

(a) concavity

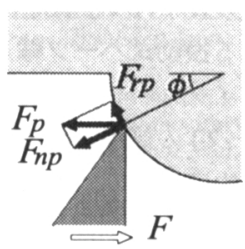

(b) convexity
Fig. 5 Point contact between micro-part and sawtooth

で表す。パーツの凹凸部とフィーダ表面ののこぎり歯 一枚との接触は, 図 5 に示すような先端部分が接触寸 る場合と, 図 6 に示すような斜面側が接触する場合に 分けられる. 本研究の目的は, 先端接触状態ではすべ りを生じさせず，斜面接触状態においてのみすべりを 


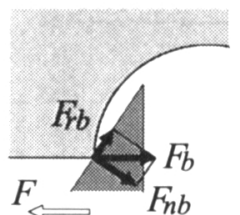

(a) concavity

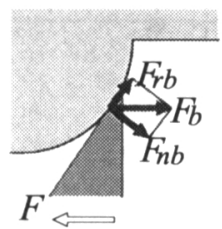

(b) convexity
Fig. 6 Slope contact between micro-part and sawtooth

生じさせることにより，一方向の輸送を行うことであ る. 本章では, それぞれの接触状態において，フィー ダからワークに伝わる駆動力の理論的検討を行うこと により，一方向輸送を実現するための条件を明らかに する.

図 5 に示寸先端接触において, パーツフィーダの振 動による駆動力を $F_{p}$ とする，パーツの凹凸とのこぎ り歯の接触点と，凹凸を示寸円の中心を結ぶ直線が水 平線と成寸角を $\phi$ とする。このとき，ワークに伝わる 力は, 次式で示すように法線方向の分力 $F_{n p}$ と接線方 向の分力 $F_{r p}$ で表される.

$$
\begin{aligned}
& F_{n p}=F_{p} \cos \phi \\
& F_{r p}=F_{p} \sin \phi
\end{aligned}
$$

ここで, ワークが十分微小かつ軽量であり，慣性力の 影響が凝着力の影響に比して十分小さいと仮定する. 接触点における凝着力の影響を含む見かけの摩擦係数 を $\mu_{e}$ とすると，ワークとのこぎり歯の間にすべりが 生じない条件は, 式 (3) で与えられる.

$$
F_{r p}-\mu_{e} F_{n p}=F_{p} \sin \phi-\mu_{e} F_{p} \cos \phi<0
$$

同様に，図6の斜面接触において駆動力を $F_{b}$ とする と, ワークに伝わる力は, 斜面の法線方向の分力 $F_{n b}$ と水平方向の分力 $F_{r b}$ で表される.

$$
\begin{aligned}
& F_{n b}=F_{b} \sin \theta \\
& F_{r b}=F_{b} \cos \theta
\end{aligned}
$$

接触点での摩摖係数を $\mu_{s}$ とすると, 寸べりの生じる 条件は以下の式で表される。

$$
F_{r b}-\mu_{s} F_{n b}=F_{b} \cos \theta-\mu_{s} F_{b} \sin \theta>0
$$

したがって，パーツフィーダ表面ののこぎり歯形状 とワークの表面との接触状態が, 式 (3) と式 (6) の条 件，すなわち

$$
\mu_{e}>\tan \phi
$$

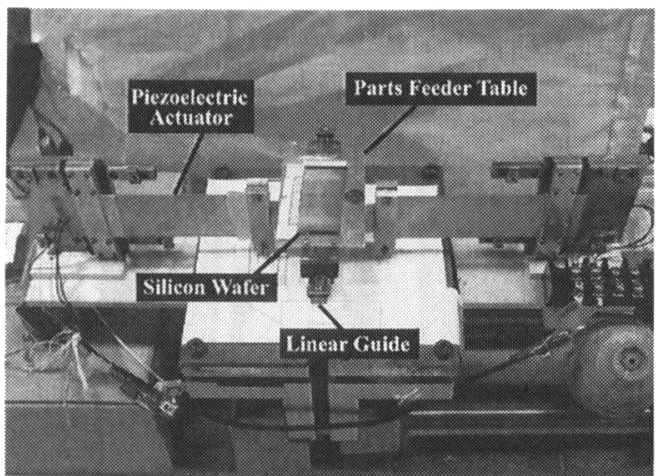

Fig. 7 Linear partsfeeder using bimorph piezoelectric actuators

$$
\mu_{s}<\frac{\cos \theta}{\sin \theta}
$$

を同時に満たしたときに一方向輸送が実現する.

次に, 輸送の方向性が得られない場合について考え る. 式 (3) が満たされない場合, すなわち

$$
\mu_{e}<\tan \phi
$$

のとき, 先端接触においてす心゙りが生じる.しかし, 図 5(a) に示寸凹部での接触では接触位置の角度 $\phi$ が 減少していき, 最終的に $\mu_{e}>\tan \phi$ が満たされるの で, すべりの生じない条件での駆動となる。また, 図 5(b)に示す凸部の接触においては， $\phi$ が増加する方向 へ寸べり, $\phi=90^{\circ}$ を超えた時点で非接触運動一と移 行寸る。しかし，隣ののこぎり歯の先端が突起に接触 し, すべりの生じない条件へ移行する。ただし，パー ツフィーダの振幅が十分でない場合には, すべり状態 からすべりの生じない運動状態への移行が行われにく く，輸送効率が低下寸る。また，式 $(8)$ より，

$$
\theta>\tan ^{-1} \frac{1}{\mu_{s}}
$$

となる $\theta$ を選択した場合には斜面接触点でのすべりが 生じず, 輸送の方向性が得られない.

次章以降では, パーツフィーダ表面の加工による見 かけの摩摖力の変化を摩摖角計測実験により明らかに し，のこぎり歯の仰角やフィーダの振動数を変えた場 合のワークの運動を実験により確かめる.

\section{3. 実験 装 置}

$3 \cdot 1$ パーツフィーダ駆動装置図 7 および図 8 に実験装置の写真および駆動システムの概略図を示す. 駆動用アクチュエータとして, バイモルフ型圧電素子 を 2 枚用いる。一端を固定端支持としたバイモルフ型 


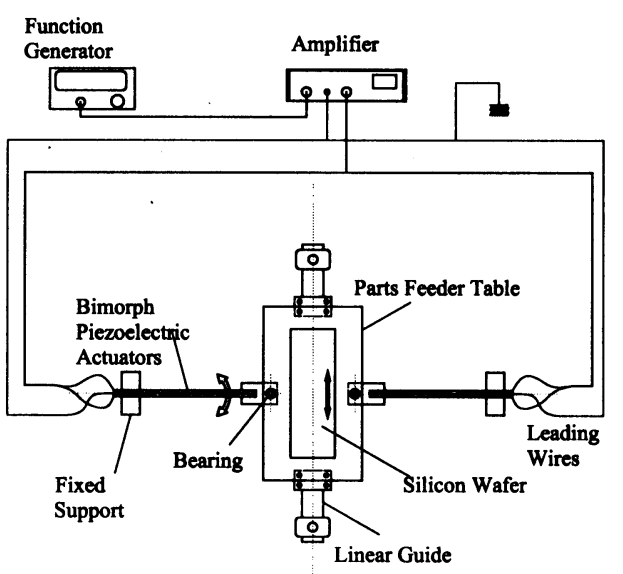

Fig. 8 Driving system of the proposed mechanism

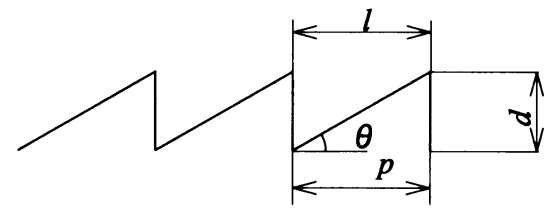

(a) saw-tooth surface

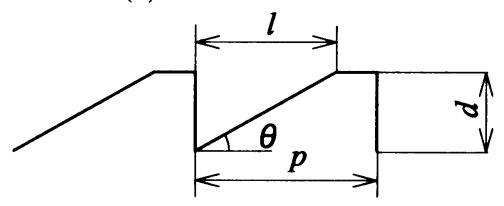

(b) trapezoidal surface

Fig. 9 Two types of surface shape of silicon wafer

圧電素子の屈曲振動を, ベアリングを用いた回転端を 介してフィーダテーブルに伝達し, フィーダテーブル の往復運動として得る機構である. フィーダテーブル は，振動が同一直線上に限定されるようにリニアガイ ドに固定されている.また, バイモルフ型圧電素子の 固定端側には，屈曲振動による長手方向の変位に対す る補償機構を備えている. 駆動信号源として関数発生 器を用い,メステック製の圧電アクチュエータ駆動用 増幅器により 30 倍に增幅し, 圧電素子へ電圧を印加 する. フィーダ表面には，表面加工を施したシリコン ウェハを用いる.

$3 \cdot 2$ フィーダ表面＼cjkstart本論文では，パーツフィー ダ表面として，のこぎり柬形状に加エしたシリコン ウェ八を用いる. シリコンウェ八の加工には, ディス コ製のダイシングソーを用いた。 ダイシングソーは, 円形のダイヤモンドブレードを高速回転させ、加工点

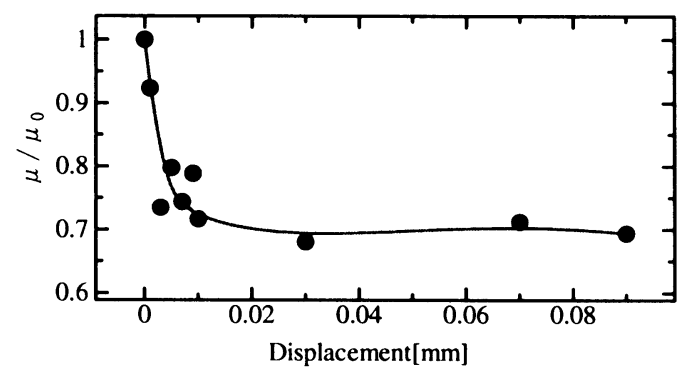

Fig. 10 Relationship between friction and groove depth of parts feeder

に冷却水をかけながら切断・溝掘りを行う装置で，ミ クロン単位の加工精度が得られるという特徴を持つ. 本研究では，のこぎり歯形状を形成するために三角形 状のブレードを用いて加工を行った．この場合，加工 条件によって図 9(a)(b) に示される 2 つの形状が得ら れる. ここで, $p$ はブレードの送り幅 (ピッチ), l は切 り込み長さ, $d$ は溝染さ, $\theta$ は满の仰角であり, $p=l$ の時に表面は図 $9(\mathrm{a})$ に示すのこぎり歯形状に, $p>l$ の時に図 9(b) に示す台形形状になる.

\section{4. 基 礎 実 験}

$4 \cdot 1$ 漸加エによる㢈擦低減效果 マイクロトラ イボロジにおいては, 摩擦力は垂直荷重と凝着力の和 に比例する ${ }^{(10)}$. ファンデルワールスカに起因する凝 着力は，実際に接触していない部分において，2 面間 の距離すなわち满深さに反比例する ${ }^{(11)}$. そこで，接 触面積を一定に保持したまま满深さを変更し, そのと きの 2012 型の摩擦角を計測することにより凝着力の 変化を確かめる. ここでは, 図 9(b) の表面において, $p=0.1 \mathrm{~mm}, l=0.05 \mathrm{~mm}, \theta=90^{\circ}$ とし, 溝哚さを $d=0 \mathrm{~mm}$ から $0.09 \mathrm{~mm}$ まで変化させた. 図 10 に, 横 軸に满深さ, 縋軸に各满深さでの摩擦角 $\mu$ と末加工の シリコンウェハにおける摩擦角 $\mu_{0}$ との比 $\mu / \mu_{0}$ をとっ た場合の計測結果を示す．满深さ $0.001 \mathrm{~mm}$ で摩擦角 は末加工時の約 $90 \%, 0.01 \mathrm{~mm}$ で約 $70 \%$ となり, そ の後はほぼ一定である. 従って, 接触面積を 50 \%にし た場合には最大 $30 \%$ の摩擦力低減効果が得られ, 凝 着力による影響を排除するには $0.01 \mathrm{~mm}$ 以上の溝深さ が必要であることがわかる.

4.2 方形波眍功時の周波数-变位曲線圧電素 子への印加電圧として $V_{p-p}=180 \mathrm{~V}$ の方形波を与え た場合のパーツフィーダの周波数-変位特性を図 11 に 示す. $10 \mathrm{~Hz}$ 駆動での変位は約 $5 \mathrm{~mm}$ であり, $15 \mathrm{~Hz}$ で 


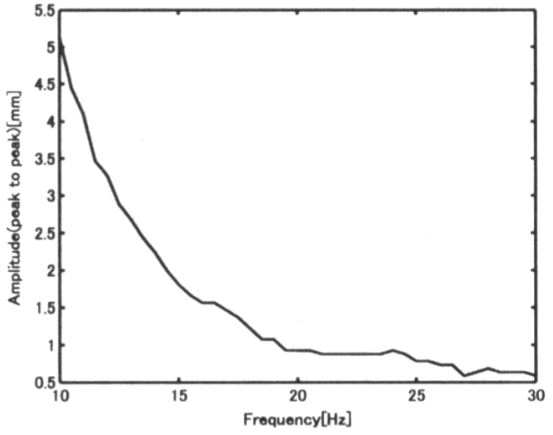

Fig. 11 Relationship between PZT driving frequency and feeder displacement

Table 2 Surface shape parameter

\begin{tabular}{|c|c|c|}
\hline Type & $\mathbf{3 0}^{\circ}$ & $\mathbf{6 0}^{\circ}$ \\
\hline$\theta[\mathrm{deg}]$ & 30 & 60 \\
\hline$p[\mathrm{~mm}]$ & 0.1835 & 0.0557 \\
\hline$l[\mathrm{~mm}]$ & 0.1835 & 0.0557 \\
\hline$d[\mathrm{~mm}]$ & 0.1250 & 0.1250 \\
\hline
\end{tabular}

は $10 \mathrm{~Hz}$ の約 $40 \%, 30 \mathrm{~Hz}$ では約 $10 \%$ に低下してい る. 寸なわち, 周波数を上げるにつれて振動振幅が低 下することがわかる。

\section{5. 輸 送 実 験}

本章では, 表 2 に示寸フィーダ表面を用いて輸送実 験を行う，以下では, 2012 および 1005 のワーク輸 送の方向性を確認し，その後それぞれのワークについ て輸送実験を行う。

$5 \cdot 1$ 輸送の方向性本研究では, ワークの凹凹に よりワークが一方向一輸送されることを確認するため に，凹凸のない試験用ワークとして $2.0 \mathrm{~mm} \times 1.0 \mathrm{~mm} \times$ $0.5 \mathrm{~mm}$ のシリコンウェハ片を用い, セラミックコン デンサとの運動を比較する．フィーダ表面には表 2 の $30^{\circ}$ タイプを使用し, 駆動信号の電圧を $120 \mathrm{~V}$, 周波数 を $15 \mathrm{~Hz}$ とし，のこぎり歯形状の傾斜面が奥行き側の 場合 (正方向配置) と手前側の場合 (負方向配置)につい てそれぞれ実験を行い。ワークの運動をフォトロン製 の高速度カメラ FastCam を用いて撮影した。フィー ダ表面の長さは約 $3 \mathrm{~cm}$ である.

FastCam を用いて約 4 秒間撮影し, 連続写真加工を 行った結果を図 12(a)(b) に示寸。なお， A は 1005, B はシリコンウェ八片，C は 2012 である. 正方向に おいて，1005，2012 はそれぞれ一方向輸送が実現さ れているのに対し, シリコンウェハ片は前進と後退を

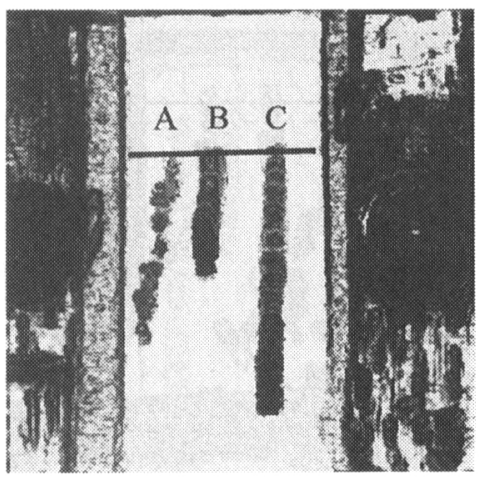

(a) positive direction

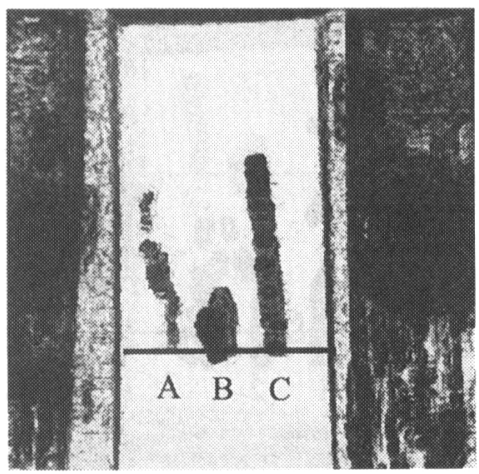

(b) negative direction

Fig. 12 Directionality of feeding

絽り返し, 輸送距離は 1005 の約半分となった。また 負方向においても，1005，2012 は一方向輸送が実現 されているのに対し，シリコンウェハ片は同一方向一 運動を開始した直後に後退し, 最終的にほぼ初期位置 まで後退した。 したがって，凹凸のないシリコンウェ 八片では運動の方向性が得られず，凹凸のあるワーク においては一方向輸送が実現されることを確認した。

\section{$5 \cdot 22012$ 型の輸送実験}

$5 \cdot 2 \cdot 130^{\circ}$ 表面を用いる場合 フィーダ表面と して, 表 2 に示す $\theta=30^{\circ}$ のシリコンウェ八を用いて, 2012 型のワークの輸送実験を行った. $10 \mathrm{~Hz}$ 駆動時で の実験結果を図 13(a)(b) に示す. 正方向配置におい ては, 駆動中にワークの回転や跳躍, 横転が頻繁に生 じており，輸送は不安定である，逆方向についても同 様に輸送方向の反転が生じている.

$15 \mathrm{~Hz}$ 駆動の場合を図 14(a)(b) に示す.ここでは約 4 秒間撮影した。正負方向どちらとも良好な実験結果 が得られた. また, シリコンウェハの配置によってワー クの輸送方向が反転することが確認された.

図 15(a)(b) に, $30 \mathrm{~Hz}$ 駆動時において約 8 秒間撮影 


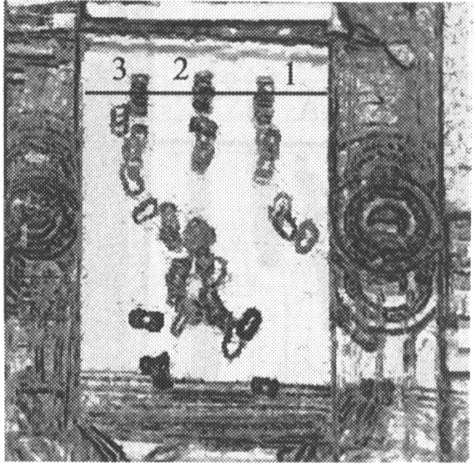

(a) positive direction

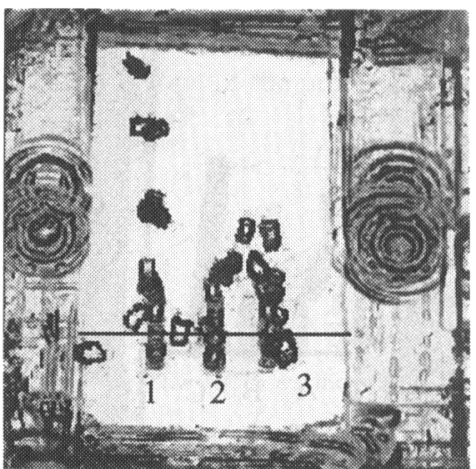

(b) negative direction

Fig. 132012 Motion at $10 \mathrm{~Hz}$ square wave on $\theta=$ $30^{\circ}$ surface

した結果を示す。この場合，運動の方向性は見られる ものの輸送がほとんど行われておらず，輸送開始位置 からほとんど動いていないワークも存在する.

\section{$5 \cdot 2 \cdot 260^{\circ}$ 表面を用いる場合 フィーダの表} 面を $\theta=60^{\circ}$ のシリコンウェハに変更し, 前項の輸送 実験でもつとも良好な結果が得られた $15 \mathrm{~Hz}$ 駆動と同 一の駆動条件で実験を行った．約 2 秒間の撮影結果を 図 16(a)(b) に示寸. 正方向においては, ワーク 2 の みが約 2 秒で一番下まで到達している，また，ワーク 3 は輸送中に回転しているのがわかる。ワーク 2 にお いては半分程度の輸送しか行えていない。負方向にお いては，シリコンウェハの反転にもかかわらず，ワー ク 1 は下方向に進んでいる. ワーク 2,3 は上方向に進 んでいるもののほとんど輸送されていない，従って， $\theta=60^{\circ}$ のシリコンウェハでは輸送の方向性は得られ なかった。

\section{$\mathbf{5} \cdot \mathbf{2} \cdot 3$ 考察 $5 \cdot 2 \cdot 1$ 項の実験では, $15 \mathrm{~Hz}$ での駆} 動がもっとも良好な結果が得られた。しかし， $3 \mathrm{~cm} の$

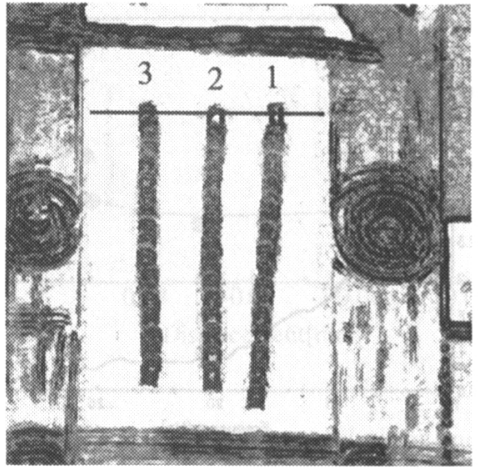

(a) positive direction

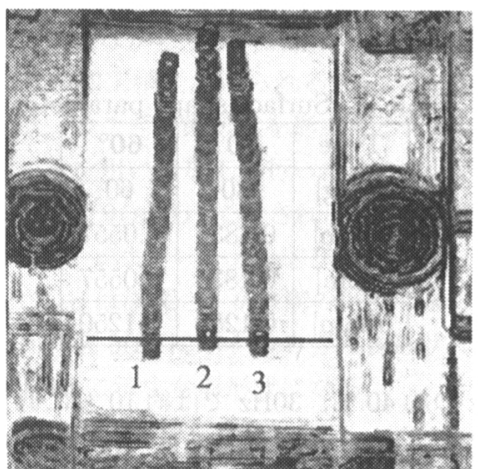

(b) negative direction

Fig. 142012 Motion at $15 \mathrm{~Hz}$ square wave on $\theta=$ $30^{\circ}$ surface

輸送に 4 秒以上かかっており, 速度の面では十分では ない。したがって, より良好な輸送条件が得られる駆 動条件や表面形状の検討を行う必要がある。10Hz 駆 動では跳躍や回転などの運動がワ一クに生じ, 安定し た輸送が行えなかった。これは，フィーダの振動振幅 が大きいために, フィーダ表面とワークの接触時にお ける衝撃力が大きく, 接触点を支点とした回転モ一メ ントが発生し, ワークの先端が浮き上がる現象が起き たと考えられる。 $30 \mathrm{~Hz}$ 駆動においては, フィーダの 振動振幅が小さすぎたため，2 章で述べたすべりを生 じない接触状態への移行が行われず，良好な輸送条件 が得られていないと考える。

$5 \cdot 2 \cdot 2$ 項の実験では, いくつかのワークにおいて $5 \cdot 2 \cdot 1$ 項の実験よりも高速な輸送が実現できている一方で, 運動の方向性は得られなかった。高速輸送が可能な理 由は, $\theta=60^{\circ}$ の表面が $\theta=30^{\circ}$ に比して凝着力の影 響が小さいためである。また，運動の方向性が得られ なかった理由としては, $\theta=60^{\circ}$ では式 (10) が成り立 


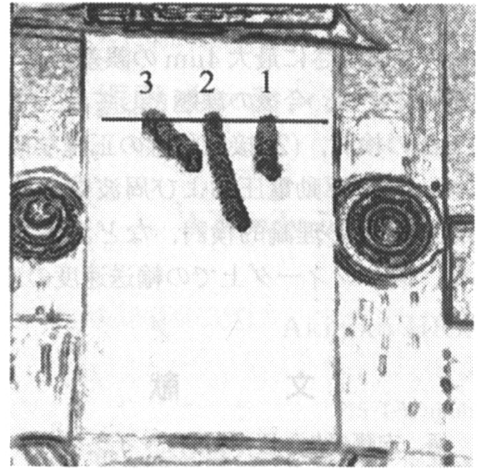

(a) positive direction

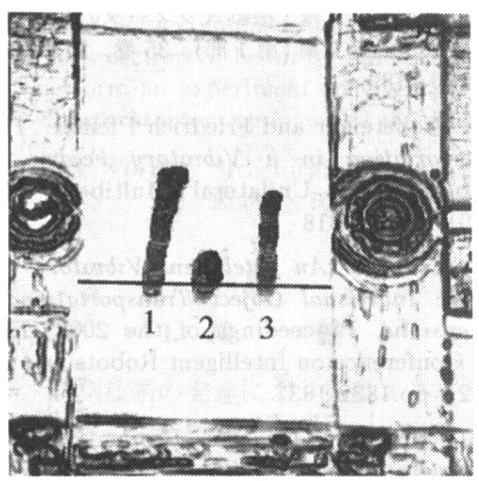

(b) negative direction

Fig. 152012 Motion at $30 \mathrm{~Hz}$ square wave on $\theta=$ $30^{\circ}$ surface

ち, 斜面接触点でのすべりが生じなかったためである と考えられる

\section{$5 \cdot 31005$ 型の輸送実験}

5·3.1 30 表面を用いる場合 次に, 2012 より 小型から軽量な 1005 型のパーツの輸送実験を行った. 実験の条件は $5 \cdot 2 \cdot 1$ 項の $15 \mathrm{~Hz}$ 駆動時之同一である。ま た，フィーダ表面として $30^{\circ}$ のシリコンウェ八を用い た。約 5 秒間撮影した結果を図 17 (a)(b)に示寸.

この場合においてもシリコンウェハの向きによって 運動の方向が変わっていることがわかる，正方向にお いては，すべてのワークにおいて左右への運動が生じ ており，ワーク 3 は他のワークに比べて輸送距離が小 さい。逆方向においては, ワ一ク 1,2 が直線的に運動 しているが，輸送距雄にばらつきが生じている.

$5 \cdot 3 \cdot 2$ 考察この実験に用いたワークである 1005 型は, 前項にて用いた 2012 型よりさらに小型 かつ軽量であり, フィーダ表面の加工精度やワークの 個体差といった要素がワークの運動に大きく影響を及

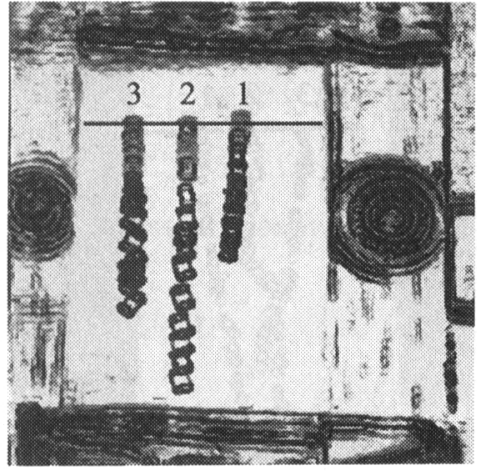

(a) positive direction

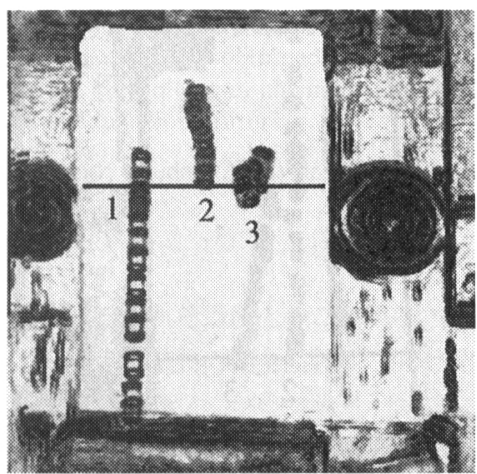

(b) negative direction

Fig. 162012 Motion at $15 \mathrm{~Hz}$ square wave on $\theta=$ $60^{\circ}$ surface

ぼす。

$5 \cdot 2 \cdot 1$ 項の $15 \mathrm{~Hz}$ 駆動との比較を行うと, 2012 型に 比べて低速な駆動になっている。これは，1005 型が 2012 より小型かつ軽量なために, フィーダの駆動に より生じるワークの慣性力が小さくなり，相対的に凝 着力による影響が大きくなったためであると思われる. また，輸送時の左右への運動は，パーツの個体差やシ リコンウェ八ののこぎり歯形状の加工精度などの要素 が接触条件の変動をもたらしたためであると推察さ れる。

6.おわりに

本研究では, バイモルフ型压電素子を用いた振動式 パーツフィーダを開発し，フィーダ表面にのこぎり歯 型の满加工を施すことによりワークの運動に方向性を 持たせる方法を提案した。フフィーダ表面に $\theta=30^{\circ}$ と $60^{\circ}$ のシリコンウェ八を用い，アクチュエータの駆動 信号として方形波を用いた場合の 2012 型の積層セラ 


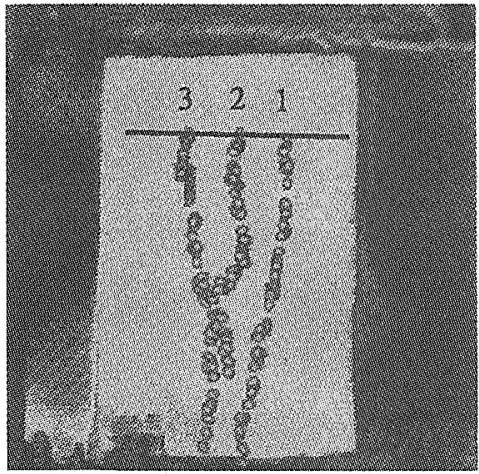

(a) positive direction

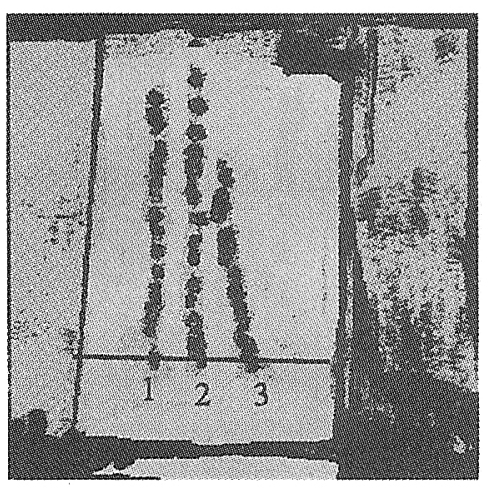

(b) negative direction

Fig. 171005 Motion at $15 \mathrm{~Hz}$ square wave on $\theta=$ $30^{\circ}$ surface

ミックコンデンサの輸送実験を行い以下の結果を得た.

- $\theta=30^{\circ}$ の表面において, ワークの運動に方向性 が見られた。

・ $\theta=60^{\circ}$ では運動の方向性は得られなかったが, 一部のワークにおいて $\theta=30^{\circ}$ より高速な輸送が 実現できた。

・ $10 \mathrm{~Hz}$ の駆動ではワークの回転や跳躍が生じ，ま た, $30 \mathrm{~Hz}$ の駆動ではワークがほとんど運動しな かった.

また, $\theta=30^{\circ}$ のフィーダ表面を用いて 1005 型の輸 送実験を行い，以下の結果を得た。

- $15 \mathrm{~Hz}$ 駆動において, 運動の方向性が確認された。

- 2010 の $15 \mathrm{~Hz}$ 駆動に比して低速であり, 運動に ばらつきが生じた。これは 2012 型に比して接触 条件の変動に影響を受けやすいためであると考え られる。

今回の実験において，1005 型の運動にばらつきが 生じた原因としては, パーツの個体差の他に, シリコ
ンウェハの加工精度によるものも考えられる．実際， のこぎり歯の先端高さに最大 $4 \mu \mathrm{m}$ の誤差を有している ことを確認している. 今後の課題としては, (1)より高 精度な加工法の検討, (2) 接触状態の正確な把握, (3) アクチュエータの駆動電圧および周波数の検討, (4) 一方向輸送の条件の理論的検討, などが挙げられる. 最終的には，同一フィーダ上での輸送速度の変更を実 現したい.

\section{文献}

（1）藤澤 悟, 安藤泰久, 榎本祐嗣: マイクロスケール摩擦 と表面間力，トライボロジスト, Vol.44, No.6, (1999), pp.409-413

（2）坂口克己, 谷口 修: 振動式フィーダの研究 (第 2 報), 日本機械学会論文集 (第 1 部)，35 巻, 279 号, (1969), pp.2183-2189

(3) Peter Wolfsteiner and Friedrich Pfeiffer: The Parts Transportation in a Vibratory Feeder, IUTAM Symposium on Unilateral Multibody Contacts, (1999), pp.309-318

(4) Peter U. Frei: An Intelligent Vibratory Conveyer for the Indivisual Object Transportation in Two Dimensions, Proceedings of the 2002 IEEE/RS.J Intl. Conference on Intelligent Robots and Systems, (2002), pp.1832-1837

(5) W.A. Morcos: On the Design of Oscillating Conveyors -Case of Simultaneous Normal and Longitudinal Oscillations-, ASME, Journal of Engineering for Industry, Vol.92, No.1, (1970), pp.53

（6）石坂昭夫，木村幹雄，小滝富雄：高次振動を利用した 振動輸送機，精密機械，Vol.39，No.1，(1973)，pp.93

（7）井沢実，野崎卓二：複合振動板による振動輸送の研究 (第 1 報)，精密機械，Vol.41，No.5，(1975)，pp.453

(8) Winncy Y. Du, Stephen L. Dickerson: Modelling and Control of A Novel Vibratory Feeder, Proceedings of the 1999 IEEE/ASME International Conference on Advanced Intelligent Mechatronics, September 19-23, (1999), Atlanta, USA, pp.496-501

（9）安藤泰久, 田中敏幸, 伊能二郎, 角田和雄 : ナノメー トルスケールの表面形状と摩擦力・引き㰚し力の関係, 日本機械学会論文集 (C 編), Vol.65, No.637, (1999), pp.3784-3791

(10) Yasuhisa Ando, Jiro Ino: The Effect of Asperity Array Geometory on Friction and Pull-Off Force, Transactions of the ASME, Vol.119, (1995), pp.781787

（11）安藤泰久：マイクロトライボロジー, 精密工学会誌, Vol.67, No.12, (2001), pp.1916-1919 